cussed "Structure and Functions of Procaryotic Cells", Dr. A. Virtanen (Finland), who discussed "Milk Production without Proteins", and Dr. S. Ochoa (United States) on "Replication of Nucleic Acids in Viruses Containing R.N.A.". Of the remaining seventeen contributorsEuropean, North American and South American-some dealt with plant endocrinology, the terminal oxidases of plants, acetyl co-enzyme $A$ carboxylation reactions, and the implications of biological catalysis ard of photosynthesis. There were three papers on neurophysiology, including one on the molecular aspects of curarization, two on antibiotics and three on experimental or population genetics. The session ended with rather a mixed collection of papers on human endocrinology, inflammation, the role of magnesium in mammalian life, and a new technique in electron microscopy.

Varied as the subjects were, there was no doubt, judging from the discussion and comments, that all of them in one way or another were of immediate interest both to the guests and to the Spanish biologists who were present.

The programme of the colloquium on the "Contributions of Ecological and Agricultural Research in the World Fight against Hunger" was made up of six sessions and a total of thirty-nine contributions. Spanish speakers predominated, but there were others from most Continental countries, Great Britain and America. A wide range of topics was discussed. Some were concerned with the broad principles of world production, others related to more specific problems of the Mediterranean region.

On a world basis, the importance of a more detailed knowledge of climatic conditions and vegetational, ecological and soil types was stressed, while the value of accurate maps for evaluation and comparison of the potential productivity of different regions was emphasized.

Another aspect was the place and role of food production in the national economy of developed and developing countries. For example, in many parts of the world water is the major factor limiting agricultural production, and careful consideration must be given to determining the best means of sharing the limited supplies between industrial, domestic and agricultural needs. Besides discussion of the water factor, there were papers concerned with the ultimate limits of productivity, nitrogen fixation and the most effective uses of fertilizers and of the ever-increasing range of ohemicals used in both agriculture and forestry.

In the colloquium on the "Physical Chemistry of Processes on Solid Surfaces" twenty-four papers were presented. The first, by P. J. W. Debye, on surface determination by $\mathrm{X}$-ray scattering, set a high standard which was well maintained. The contributions ranged over the whole field of the relationship between surface structure and catalysis, including the use of radioisotopes in the examination of surface phenomena. Among those present were many of the leading authorities, and this ensured an unusually penetrating discussion of the many now ideas put forward. The colloquium, indeed, was an outstanding success, and it is good to know that the papers and discussions will be published in full.

The proceedings closed with a banquet on October 24 at which speeches of thanks and congratulations were made by visitors from Great Britain, Germany, Argentina and France. Reply was made by the Minister of National Education, Dr. Lora Tomayo, who presided at the banquet, and who was, until a few years ago, professor of organic chemistry in the Consejo's laboratories. His appointment as Minister was, indeed, a most interesting and welcome sign of the times, and an earnest of Spain's determination to put her scientific and technological development in the forefront of her programme.

Besides the banquet there was a full social programme which enabled visitors to meet one another and their Spanish colleagues and hosts under most agreeable conditions, and on the Sunday after the meetings an excursion was arranged to the Valle de los Caidos and the Escorial. All arrangements were excellently made, and our Spanish hosts were most generous.

Visitors were left with an impression of a great Spanish achievement. Not only has the Consejo firmly establishod itself over a wide field of learning and research, but also present plans envisage a rapid growth, particularly in buildings and facilities. At present, in many laboratories, the space available scarcely matches the excellence of the staff.

The work of the Consejo is likely to have a profound long-term influence on Spanish thought and organization. For this much of the credit must go to J. M. Albareda. It is pleasant for us to reflect that he once spent two years in Britain as a Ramsay Memorial Fellow.

B. K. Blount

\title{
OBITUARIES
}

\section{Prof. J. M. Somerville}

JACK MURIELle Somerville, professor of physics in the University of New Fngland, diod suddenly on October 15,1964 . Though his silver hair made him look older, he was only fifty-one.

Born at Liverpool, Now South Wales, in 1912 and educated at Wollongong High School and the University of Sydney, he began his carcer as a mathematician and on graduation won a Barker scholarship to Emmanuel Col. lege, Cambridge. When he returned to Australia in 1937, however, his main interest turned to physics and in 1938 he was appointed as one of the foundation members of the staff of the New England University College, whore he was in charge of all teaching in both mathematics and physics. Thus began his long association with the present University of New England, an association interrupted for only four years during the Second World War when he returned to the University of Sydnoy as assistant director of radiophysics training in a war-time school to train operators and technicians in the then new science of radar. In 1954, when the College became autonomous as the University of New England, he was appointed as its foundation professor of physics and continued as head of the Department of Physics until his death.
Prof. Somerville's main research interests lay in the study of electric discharges in gases. His earlier work on discharges in magnetic fields earned him a D.Sc. from the University of Sydney in 1952, but he is chiefly known for his work on transient electric ares and sparks which occupied the last fifteen years of his life. He liked to use a simple direct approach to physical problems whenever possible and developed a method for the study of spark channels, by which a current pulse, passing through the plasma of the channel, was made to leave an imprint on a thin insulating film covering the anode. From a study of these imprints the life history of a spark could be traced in detail over the first few microseconds of its existence. Later refinements of the work extended optical, spectroscopic and calorimetric methods to the study of these sparks.

Recognition of his work was wide and his circlo of personal friends included many people working in related fields in the United Kingdom, Europe and America. $\mathrm{H}_{\Theta}$ spent 1952-53 as Warren Research Fellow of the Royal Society at the University College of Swansea, and an extended trip in 1963 allowed him to visit many laboratories where work related to his interests was being carried on. 
His influonce on seienco in Australia was considerable and he was much sought after to servo on important committees both within and outside the University. $\mathrm{He}_{e}$ was a council member and past president of the Australian Institute of Nuclear Science and Enginoering, a member of the committoc at present drafting a now science syllabus for secondary schools in New South Wales and a member for many years of the Council of the University of Now England.

Prof. Somerville's wise and kindly influence on his many students and colloagues will be long remombered, as will his contribution to the establishment of the University of Now England.

N. H. Flewther

\section{Mr. C. C. L. Gregory}

Mr. Gregony, who was killed in a street accident on November 24, 1964, will be remembered as the astronomer who set up the Univcrsity of London Observatory at Mill Hill. However, he had many othor interests and activities.

He was born on May 13, 1892, and developed an interest in astronomy in early life. He gained a B.A. honours degree at the University of Cambridge in 1915 and started research at the Imperial College of Science and Technology, London, where the Diplorna of tho Imperial College was conferred on him in 1917. From studying the ammonium spectrum in London, he went, in 1919, as chief assistant to the Helwan Observatory, Egypt, there to make a major contribution to the photographic survey of nebulae with the 36 -in. Reynolds reflector.

From 1921 he was lecturer in astronomy in the Mathematies Department of the University College, London. However, Mr. Gregory was a practically minded astronomer, and talk of a research observatory was soon oponed between him and Prof. Filon. About 1924 a 24-in. reflecting telescope was found to be available. This was accepted from Mr. F. G. Wilson (County Westmeath) and erected in 1929 at Mill Hill. Mr. Gregory became the Wilson Observer. Under his direction the Observatory continued to expand - the large Radeliffe twin refractor was erected in 1939. He mixed day-time lecturing with Observatory management and night observing. He kept up a centre of undergraduate astronomical teaching in the University College at a time when other university observatories were turning preforentially to postgraduate studies.

Throughout his life he had a strong interest in parapsychology and metaphysics, and in 1950 he resigned from astronomy to turn completely to such subjects. In 1954 he was joint author with Anita Kohsen of a book entitlod Physical and Psychical Research (An Analysis of Belief). Later, Mr. Grogory and Miss Kohsen were married. Jointly they set up the Institute for the Study of Mental Images and brought out a journal entitled Cosmos. This journal was to terminate with its forty-first number, and by tragic eoincidence Mr. Gregory's death occurred while No. 41 was being prepared, C. W. Allew

\section{NEWS and VIEWS}

Biological Sciences in the College of Advanced
Technology, Birmingham:

DR. A. J. MatrY, who is at present senior lecturer in comparative pharmacology in the University of St. Andrews, has been appointed professor of biological sciences and head of the new Department at the College of Advanced Teohnology, Birmingham, as from January 1. Dr. Matty, who is forty years old, was educated at the Central Grammar School, Birmingham, and at University Colloge, Nottingham, where in 1948 he took a B.Sc. (Special) London External degree in zoology. In 1951 he obtained his Ph.D. at the University of Nottingham. Dr. Matty began his career as a demonstrator in zoology at the University of Nottingham, where ho was later appointed lecturer. In 1959 he became lecturer at the University of St. Andrews, where, at the newly built Wellcome Laboratories of Pharmacology at tho Gatty Marine Laboratory, he established teaching and researeh in comparative pharmacology. Dr. Matty's research has beon concerned with comparative and cellular endocrinology, particularly on problems of thyroid function in lower animals. Ho was awarded one of the first Royal Society and Nuffield Foundation Commonwealth Bursaries in 1955 for research in Bermuda on the thyroid gland of Scarus guamacia. Other research work carricd out by Dr. Matty has been concerned with the effect of thyroid hormones on membrane pormeability, on the pituitaries of fishes, on cyclostome endocrinology, and on intestinal transport in mammals.

\section{Mathematics in the University of Keele :}

\section{Prof. A. P. Robertson}

Dr. A. P. RoBertson, whose appointmont to the chair of mathematics in the University of Keele in succession to Prof. D.S. Jones was announced recently, was born in 1925. He pursued his undergraduato studies in tho University of Glasgow, graduating M.A. with first-class honours in mathematics and natural philosophy early in 1946. Because of the requirements of the National
Service Act he was not able to leave Clasgow to continue his studies elsewhere and acted as an assistant lecturer in mathematics until October 1947, when he entered St. John's College, Cambridge, to read for the Mathematics Tripos. He gained a B.A. of the University of Cambridge in 1949 and Ph.D. in 1954 (being elected a Fellow of his own college in that year). Apart from a year in the University of Kansas, Dr. Robertson has been on the mathematics staff of the University of Glasgow since 1961, first as a lecturer and latterly as a senior lecturor. Dr. Robertson is well known for his original contributions to 'classical' analysis and functional analysis. This year saw the publication of the Cambridge Mathematical Tract Topological Vector Spaces written by Dr. Robertson and his wife; this has already boen acclaimed as a most useful survey of an important part of functional analysis. His interest in reforms in the mathematical curriculum both at school and university, as well as his status as a research worker in an important branch of modern pure mathematics, fit him armirably for the chair he is now called to occupy.

Physics in the University of Leeds: Prof. F. E. Hoare

Dr. F. E. HoARe, reader in physics in the University of Leeds, has been appointed to an additional chair in the Department of Physics in the University. Dr. Hoare was educated at the Municipal Secondary School, Brighton, and the Imperial Colloge of Science and Technology, London. He gained first-class honours in physics in the examinations for the degree of B.Sc. and Associateship of the Royal College of Science. $\mathrm{He}$ was awarded the degrees of M.Sc. in 1930 and Ph.D. in 1932 for work on radiation measurements. In 1928 Dr. Hoare was appointed assistant lecturer in physics at the then University College, Exeter, and was promoted to a lectureship in 1934 . During the Second World War he was engaged on scientific work for the Admiralty. He joined the University of Leeds in 1946 as lecturer in physics and was promoted to a sonior lectureship in 1952 and a readership in 1954. 